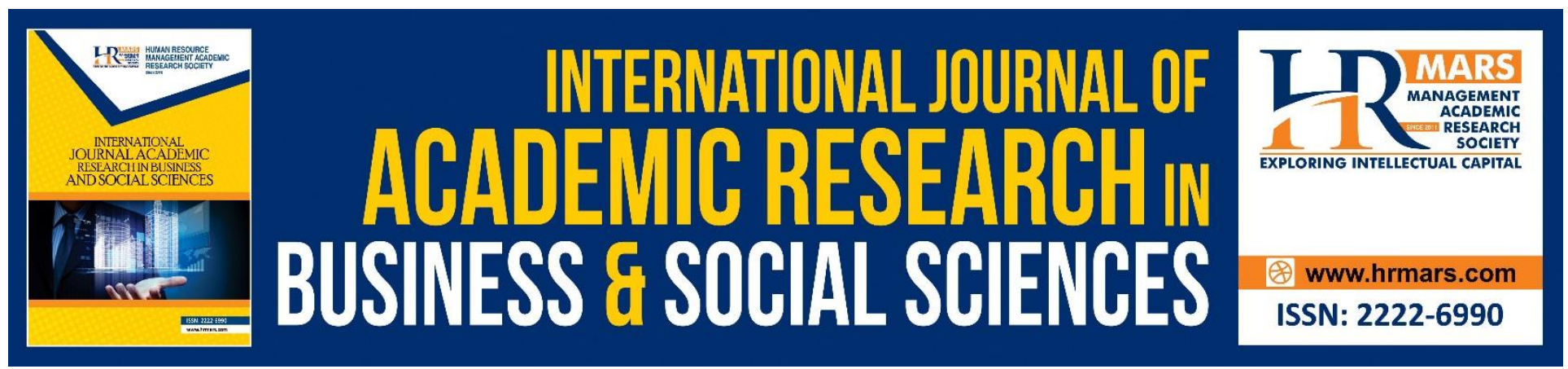

\title{
Angel Investors in Indonesia's Creative Industry: Profile and Role
}

\author{
Inda Arfa Syera, Masnia Nasution, Andri Zainal
}

To Link this Article: http://dx.doi.org/10.6007/IJARBSS/v8-i7/4397

DOI: $\quad 10.6007 /$ IJARBSS/v8-i7/4397

Received: 01 June 2018, Revised: 19 June 2018, Accepted: 29 June 2018

Published Online: 28 July 2018

In-Text Citation: (Syera, Nasution, \& Zainal, 2018)

To Cite this Article: Syera, I. A., Nasution, M., \& Zainal, A. (2018). Angel Investors in Indonesia's Creative Industry: Profile and Role. International Journal of Academic Research in Business and Social Sciences, 8(7), 554-564.

Copyright: (C) 2018 The Author(s)

Published by Human Resource Management Academic Research Society (www.hrmars.com)

This article is published under the Creative Commons Attribution (CC BY 4.0) license. Anyone may reproduce, distribute, translate and create derivative works of this article (for both commercial and non-commercial purposes), subject to full attribution to the original publication and authors. The full terms of this license may be seen at: http://creativecommons.org/licences/by/4.0/legalcode

Vol. 8, No. 7, July 2018, Pg. 554 - 564

http://hrmars.com/index.php/pages/detail/IJARBSS

JOURNAL HOMEPAGE

Full Terms \& Conditions of access and use can be found at http://hrmars.com/index.php/pages/detail/publication-ethics 


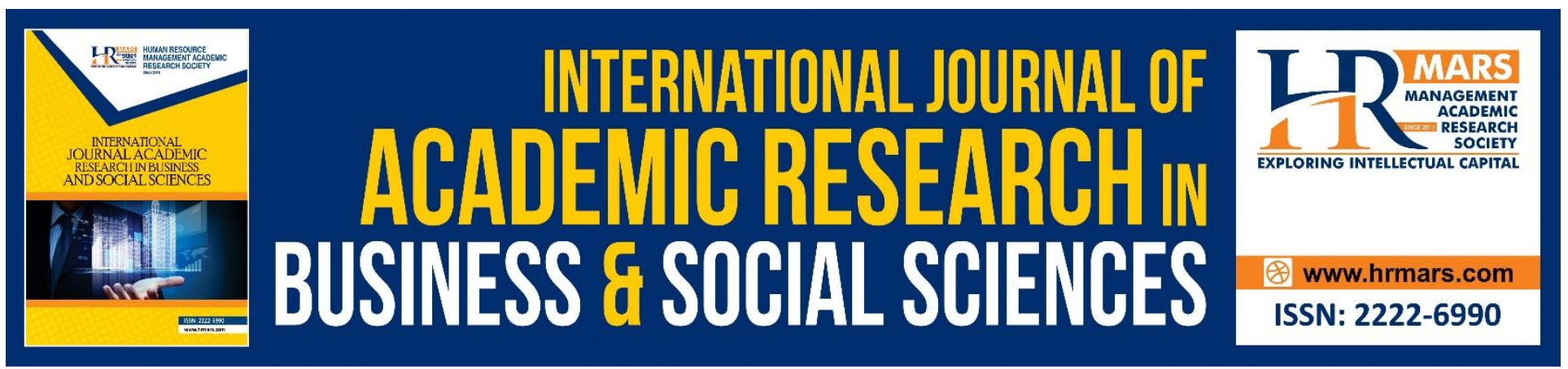

\title{
Angel Investors in Indonesia's Creative Industry: Profile and Role
}

\author{
Inda Arfa Syera, Masnia Nasution, Andri Zainal \\ Post Graduate of Economics, Universitas Negeri Medan, Medan, Indonesia \\ * Corresponding Author: indaarfas@yahoo.com
}

\begin{abstract}
This paper intends to provide the most recent reviews regarding the development and funding patterns of angel investment into the creative industries in Indonesia. In particular, this paper explores the role of angel investors in creative industries in Indonesia, angel investor-funded industry sectors, angel investor investment patterns, and potential sectors of creative industry that can be considered as an investment destination for angel investors. Although there is no rigid and up-todate data on the role and contribution of angel investors to the development of creative industry and national economic growth in Indonesia, the qualitative study in this paper indicates the relatively significant potential of the existence of start-up companies supported by angel investorstowards expanding their business scope in the future. This paper also presents a brief profile of angel investors in Singapore in comparing description and structure of angel investment funding within the creative industry between Indonesia and Singapore. The implications of this study are also discussed in the closing section of this paper.
\end{abstract}

Keywords: Angel Investment, Creative Industry, ANGIN, SGAN

\section{Introduction}

Funding is an important aspect that determines the level of business development at various levels; not only for corporation business but also for individual business. In general, Busenitz et al. (2017) has classified venture capital (VC), venture capital (CVC), angel investment, crowd-funding and accelerators as five main funding sources in the contemporary business practice.Specifically, Busenitz et al. (2017) highlights one alternative investment source of investment that has a significant role for the growth of a business. However, relevant studies on the role of investment angel are relatively lacking.

Angel investment is currently known as one of major alternative of investing in businesses in the early stages (Morrissette, 2007; Li et al., 2014). Due to the nature of his private and informal investments, angel capital is a better option for seeking capital investment (Wong, Bhatia, \& Freeman, 2009). Historically, many wealthy people have become generous by investing in creative works of artists (Anderson, 1996). These philanthropists (also known as angel investors) show capital investment practices in the creative industries. Angel investment is a term for investments made by investors commonly referred to as angel. 
INTERNATIONAL JOURNAL OF ACADEMIC RESEARCH IN BUSINESS AND SOCIAL SCIENCES Vol. 8, No. 7, July 2018, E-ISSN: 2222-6990 @ 2018 HRMARS

Today, most of the angel investors are prominent individuals who have large funds and are willing to fund companies that are developing business in the early stages. Specifically, the entrepreneur at the beginner level in the digital age is now concentrating on creative industries that not only need capital assistance but also technical guidance of business development. These two roles are characteristic of angel investment patterns that are not purely commercial or profitoriented (Busenitz et al., 2017; Huang and Pearce, 2015).

The development of the creative industry in Indonesia is also particularly prominent and received special attention from the government in the era of Joko Widodo regime through the establishment of Creative Economy Agency (BEKRAF) which is a ministerial level governmental institution. Despite having considerable contribution, but many problems encountered in the development of creative industries in Indonesia, one of which is the lack of access to finance.

According to data from the Ministry of Tourism and Creative Economy (Kemenparekraf), in 2013 creative industries can contribute to gross domestic product (GDP) as much as $7.29 \%$ or worth 486.1 trillion. This contribution increased compared to the year 2012 where the creative industry can contribute to the GDP of Indonesia as much as $6.9 \%$ despite the value of 573.89 trillion rupiah. The creative industry can also absorb the workforce as much as 11.8 million or $10.72 \%$ of total workforce in Indonesia in 2013. This tends to increase compared to the year 2012 where the creative industry can absorb 8.6 million workers or $7.9 \%$ of total workforce in Indonesia in 2012.

The above data shows the potential of the creative industry in Indonesia, especially for the provision of funding access to the relevant sectors of angel investors. Since 2012, the angel in Indonesia began to be collected in a program called Angel Investment Network Indonesia (ANGIN) designed by Global Entrepreneurship Program Indonesia (GEPI) (http://entrepreneur.bisnis.com/read/20150608/88/441150/angel-investment-alternatif-).

ANGIN has evolved into a community network of prominent individuals in Indonesia to jointly collect funding, resources and expertise in their respective fields to engage in initial investment and counseling for Indonesian start-up companies. Based on information obtained from ANGIN (http://angin.id/), during the last five years, ANGIN "only" facilitates funding to 22 new entrepreneurs in various service sectors with capital allocations varying from IDR 500 million (USD 36,000.00) to IDR 1.5 billion (USD 110,000).

This paper is intended to provide the latest reviews related to the development and funding patterns angel investment into the creative industries in Indonesia. In particular, this paper explores the role of angel investors in creative industries in Indonesia, angel investor-funded industry sectors, angel investor investment patterns, and creative industry potentials as an investment destination for angel investors. This paper also presents reviews from a theoretical and practical point of view about the role of angel investors for Indonesia's economic growth through the creative industry sector that can provide the foundation for relevant research opportunities in the future. In addition, this paper also presents a comparison of the profile of creative industries supported by angel investors between Indonesia and Singapore.

\section{Angel Investor In Indonesia: Profile and Role}

In Indonesia, many start-up and popular tech startup industries are emerging by using mobile technology through applications and smartphones. Call it Go-Jek, Tokopedia, and Traveloka, as a pioneer company that evolved into a unicorn company, because it has a corporate value of more than IDR 1 trillion. Behind the success of one startup, certainly many factors that accompany it. Among 
INTERNATIONAL JOURNAL OF ACADEMIC RESEARCH IN BUSINESS AND SOCIAL SCIENCES

Vol. 8, No. 7, July 2018, E-ISSN: 2222-6990 @ 2018 HRMARS

the founding factors, investors, and their own products. One startup may not succeed, even a unicorn, without financial and technical support from angel investors.

After all, angel investors became the earliest party to believe and dare to take risks against a startup product concept, when other investors did not dare. Regardless of the reward, angel investors are with the founders with the same belief, and the greatest risk to develop ideas into products. As mentioned in the previous section, up to now there are 22 businesses that have been supported especially financially by the Indonesian angel investor network (ANGIN). Table 1. below presents a business start-up profile that has been funded by angel investors in Indonesia.

Table 1. Start-up Business Funded by ANGIN

\begin{tabular}{|c|l|l|}
\hline No & \multicolumn{1}{|c|}{ Start-up } & \multicolumn{1}{|c|}{ Sector } \\
\hline 1. & Eskimomo & Food Company \\
\hline 2. & Gandeng Tangan & $\begin{array}{l}\text { Peer to } \\
\text { Lending }\end{array}$ \\
\hline 3. & Worktrees & IT Market Place \\
\hline 4. & Du'Anyam & Handicraft \\
\hline 5. & Rework & Coworking Space \\
\hline 6. & Petlogue & Pet Tech \\
\hline 7. & Chipmunks & $\begin{array}{l}\text { Children } \\
\text { Entertaiment }\end{array}$ \\
\hline 8. & Waroeng Mee & Restaurant \\
\hline 9. & Temploy & Job Matchmaker \\
\hline 10. & Del Mare & Food Company \\
\hline 11. & Pazpo & Property Tech \\
\hline 12. & Burgreens & $\begin{array}{l}\text { Eatery } \\
\text { Catering }\end{array}$ \\
\hline 13. & Landmapp & Mobile Technology \\
\hline 14. & Kargo & Logistics \\
\hline 15. & Qontak & $\begin{array}{l}\text { Information } \\
\text { Technology }\end{array}$ \\
\hline 16. & Summit & $\begin{array}{l}\text { Healthcare } \\
\text { Education }\end{array}$ \\
\hline 17. & Teralite & Financial Service \\
\hline 18. & Marguerite & Food Company \\
\hline 19. & Krakakoa & Food Company \\
\hline 20. & Kitabisa.com & Crowdfunding \\
\hline 21. & Wangsa Jelita & $\begin{array}{l}\text { Cosmetics } \\
\text { Company }\end{array}$ \\
\hline 22. & Berry Kitchen & $\begin{array}{l}\text { Online } \\
\text { Catering }\end{array}$ \\
\hline
\end{tabular}

As contained in the ANGIN website (www.http: //angin.id/joinanginnetwork/our-angels-2/), it is currently registered as many as 61 angel investors where 15 of them are also incorporated in the Women Fund which is an affiliate network of ANGIN. 
INTERNATIONAL JOURNAL OF ACADEMIC RESEARCH IN BUSINESS AND SOCIAL SCIENCES Vol. 8, No. 7, July 2018, E-ISSN: 2222-6990 @ 2018 HRMARS

\section{Investment Pattern of Angel Investor}

There are several criteria that entrepreneurs must meet if they want to gain the benefit from this program, among them are competent and committed Indonesian citizens, start-ups are in early development stage or expansion, have a clear business strategy. After that, the business actors must register and fill out an application form that has been provided on the website gepi.co/angin. All incoming apps will be reviewed and selected.

Any business that passes the selection will follow the pitching session through presentations and interviews. Thereafter, there will be strategic, financial and operational analysis. Once elected, the company entitled to receive the investment will be evaluated, the approval of funds and equity, after which the funds are distributed to the company (http://entrepreneur.bisnis.com/read/20150608/88/441150/angel-investment-alternatif-).

\section{Funding Allocation of Indonesia's Angel Investors}

The results of the analysis by the author, ANGIN has funded 22start-upwith range of IDR500 million to IDR1, 5 billion. Although there is no definitive data on the amount of funds provided by the WIND, but if using the average value of the lowest range (IDR 500,000.000,00) to the highest range (IDR 1,500,000,000,00) it can be assumed that the nominal fund disbursed by ANGIN to start-up business in Indonesia reaches IDR 22,000,000,000 (- USD 1,570,000.00). Seeing the existing trends and the growing number of investors who merge into ANGIN also indicate the potential growth and development of start-ups that will be funded by these angels.

\section{Creative Industry as Investment Destination Angel Investor}

The main potential of the creative industry is creativity. Human resources that have the creativity needed the creative industry to develop the business owned by highlighting the uniqueness-uniqueness of the products / services offered. On the other hand, the product / service in question must also have a social impact and focus on the product target by utilizing appropriate technology in every aspect of production and marketing. Currently, BEKRAF as a government authority that overshadows creative industries in Indonesia has classified 16 sub-sectors of the creative industry consisting of: (1) application and game developer; (2) architecture; (3) interior design; (4) visual communication design; (5) product design; (6) fashion; (7) movies, animations, and videos; (8) photography; (9) craft; (10) culinary; (11), music; (12) issuance; (13) advertising; (14) performing arts; (15) fine art; and (16) television and radio (http://www.bekraf.go.id/).

Specifically, 15 of the 22 start-up funded by ANGIN can be relatively classified into several creative industry sub-sectors in accordance with 16 business sub-sectors that are BEKRAF domains. The composition can be reviewed from the groupings in Table 2 below.

Table 2. Classification of BEKRAF Creative Industrial Sub-sectors

\begin{tabular}{|c|l|l|l|}
\hline No & \multicolumn{1}{|c|}{ Start-up } & \multicolumn{1}{|c|}{ Sectors } & $\begin{array}{l}\text { Classification } \\
\text { of BEKRAF } \\
\text { Sub-sectors* }\end{array}$ \\
\hline 1. & Eskimomo & $\begin{array}{l}\text { Food } \\
\text { Company }\end{array}$ & 10 \\
\hline
\end{tabular}


INTERNATIONAL JOURNAL OF ACADEMIC RESEARCH IN BUSINESS AND SOCIAL SCIENCES Vol. 8, No. 7, July 2018, E-ISSN: 2222-6990 @ 2018 HRMARS

\begin{tabular}{|c|c|c|c|}
\hline 2. & $\begin{array}{l}\text { Gandeng } \\
\text { Tangan }\end{array}$ & $\begin{array}{l}\text { Peer to Peer } \\
\text { Lending }\end{array}$ & $\mathrm{n} / \mathrm{a}$ \\
\hline 3. & Worktrees & $\begin{array}{ll}\text { IT } & \text { Market } \\
\text { Place } & \\
\end{array}$ & 1 \\
\hline 4. & Du'Anyam & Handicraft & 9 \\
\hline 5. & Rework & $\begin{array}{l}\text { Coworking } \\
\text { Space }\end{array}$ & $\mathrm{n} / \mathrm{a}$ \\
\hline 6. & Petlogue & Pet Tech & $\mathrm{n} / \mathrm{a}$ \\
\hline 7. & Chipmunks & $\begin{array}{l}\text { Children } \\
\text { Entertaiment }\end{array}$ & $\mathrm{n} / \mathrm{a}$ \\
\hline 8. & $\begin{array}{l}\text { Waroeng } \\
\text { Mee }\end{array}$ & Restaurant & 10 \\
\hline 9. & Temploy & $\begin{array}{l}\text { Job } \\
\text { Matchmaker }\end{array}$ & 1 \\
\hline 10. & Del Mare & $\begin{array}{l}\text { Food } \\
\text { Company }\end{array}$ & 10 \\
\hline 11. & Pazpo & Property Tech & 1 \\
\hline 12. & Burgreens & $\begin{array}{l}\text { Eatery and } \\
\text { Catering }\end{array}$ & 10 \\
\hline 13. & Landmapp & $\begin{array}{l}\text { Mobile } \\
\text { Technology }\end{array}$ & 1 \\
\hline 14. & Kargo & Logistics & $\mathrm{n} / \mathrm{a}$ \\
\hline 15. & Qontak & $\begin{array}{l}\text { Information } \\
\text { Technology }\end{array}$ & 1 \\
\hline 16. & $\begin{array}{l}\text { Summit } \\
\text { Healthcare }\end{array}$ & $\begin{array}{l}\text { Healthcare } \\
\text { Education }\end{array}$ & $\mathrm{n} / \mathrm{a}$ \\
\hline 17. & Teralite & $\begin{array}{l}\text { Financial } \\
\text { Service }\end{array}$ & $n / a$ \\
\hline 18. & Marguerite & $\begin{array}{l}\text { Food } \\
\text { Company }\end{array}$ & 10 \\
\hline 19. & Krakakoa & $\begin{array}{l}\text { Food } \\
\text { Company }\end{array}$ & 10 \\
\hline 20. & Kitabisa.com & Crowdfunding & 1 \\
\hline 21. & $\begin{array}{l}\text { Wangsa } \\
\text { Jelita }\end{array}$ & $\begin{array}{l}\text { Cosmetics } \\
\text { Company }\end{array}$ & 6 \\
\hline 22. & $\begin{array}{l}\text { Berry } \\
\text { Kitchen }\end{array}$ & $\begin{array}{l}\text { Online Food } \\
\text { Catering }\end{array}$ & 1 \\
\hline
\end{tabular}

* Code description: (1) application and game developer; (2) architecture; (3) interior design; (4) visual communication design; (5) product design; (6) fashion; (7) movies, animations, and videos; (8) photography; (9) craft; (10) culinary; (11), music; (12) issuance; (13) advertising; (14) performing arts; (15) fine art; and (16) television and radio.

Based on table 2 above, see the number of BEKRAF-funded sub-sector classifications of 15 companies (68.18\%) out of a total of 22 start-ups, this proves that the creative industry has the potential to contribute to national income both in the short and long term. The statistics in question also describe the four major potential sectors in the categorical industry that have been supported by ANGIN as follows: 
INTERNATIONAL JOURNAL OF ACADEMIC RESEARCH IN BUSINESS AND SOCIAL SCIENCES

Vol. 8, No. 7, July 2018, E-ISSN: 2222-6990 @ 2018 HRMARS

1. Application and Game Developer Sub-sector (46.6\%).

2. Culinary Sub-sector (40\%).

3. Fashion sub-sector (6.7\%).

4. Kriya Sub-sector (6.7\%).

This indicates that although the creative industry sector, which has not been a major destination for conventional investors and institutional banks, remains a potential business that can support national economic growth. Specifically, ANGIN and / or other angel investor networks and can fill the funding opportunities for the sector in question and make this sector a large unicorn company in the digital age.

\section{Profile and Role of Angel Investors in the Creative Industry in Singapore}

Singapore Angel Network Pte Ltd (SGAN) is an angel investment arm of the multi-billion dollar Thakral Group of Companies. SGAN stands for the purpose of promoting a culture of entrepreneurship and to support a thriving start-up ecosystem in various countries (https://www.sgan.sg).

In relation to its role in the development of creative industry in Singapore, the Singapore Government has established the Economic Review Committee (ERC) in the period of December 2001 in which the agency is tasked to produce a formulation of Singapore's economic restructuring in the future. ERC then formed several Committees and Sub Committees, and under it again there are working groups which one of them is Creative Industries Working Group (CIWG). CIWG then categorizes the creative industries into three groups, consisting of: (1) Arts and Culture; (2) Design; and (3) Media. Based on the classification in question, there are 52 companies (65.82\%) of the 79 $\neg$ Start-ups that have been funded by SGAN. In detail, these groupings can be seen in Table 3 below.

Table 3. SGAN-funded Enterprises and Sectors

\begin{tabular}{|c|l|l|l|}
\hline No & \multicolumn{1}{|c|}{ Start-up } & \multicolumn{1}{|c|}{ Sectors } & $\begin{array}{l}\text { Classification } \\
\text { of CIWG* }\end{array}$ \\
\hline 1. & AssuredRiskCover & Analytics & n/a \\
\hline 2. & Do Seletct & Analytics & n/a \\
\hline 3. & Lens Bricks & Analytics & n/a \\
\hline 4. & Mobilewalla & Analytics & n/a \\
\hline 5. & Wigzo & Analytics & n/a \\
\hline 6. & 1efficiency & Clean Tech & 3 \\
\hline 7. & LoudCell & Clean Tech & 3 \\
\hline 8. & Bookeventz.com & $\begin{array}{l}\text { Consumer } \\
\text { Internet }\end{array}$ & 3 \\
\hline 9. & BoxMySpace & $\begin{array}{l}\text { Consumer } \\
\text { Internet }\end{array}$ & 3 \\
\hline 10. & CalLiberate & $\begin{array}{l}\text { Consumer } \\
\text { Internet }\end{array}$ & 3 \\
\hline 11. & Contag & $\begin{array}{l}\text { Consumer } \\
\text { Internet }\end{array}$ & 3 \\
\hline 12. & Explara & $\begin{array}{l}\text { Consumer } \\
\text { Internet }\end{array}$ & 3 \\
\hline
\end{tabular}


INTERNATIONAL JOURNAL OF ACADEMIC RESEARCH IN BUSINESS AND SOCIAL SCIENCES Vol. 8, No. 7, July 2018, E-ISSN: 2222-6990 @ 2018 HRMARS

\begin{tabular}{|c|c|c|c|}
\hline 13. & GreyLoft & $\begin{array}{l}\text { Consumer } \\
\text { Internet }\end{array}$ & 3 \\
\hline 14. & $\begin{array}{l}\text { India College } \\
\text { Search }\end{array}$ & $\begin{array}{l}\text { Consumer } \\
\text { Internet }\end{array}$ & 3 \\
\hline 15. & Ketto & $\begin{array}{l}\text { Consumer } \\
\text { Internet }\end{array}$ & 3 \\
\hline 16. & Lowdown & $\begin{array}{l}\text { Consumer } \\
\text { Internet }\end{array}$ & 3 \\
\hline 17. & Orahi & $\begin{array}{l}\text { Consumer } \\
\text { Internet }\end{array}$ & 3 \\
\hline 18. & Prizle & $\begin{array}{l}\text { Consumer } \\
\text { Internet }\end{array}$ & 3 \\
\hline 19. & Ridgecrest & $\begin{array}{l}\text { Consumer } \\
\text { Internet }\end{array}$ & 3 \\
\hline 20. & Scroll Back & $\begin{array}{l}\text { Consumer } \\
\text { Internet }\end{array}$ & 3 \\
\hline 21. & Shop Genius & $\begin{array}{l}\text { Consumer } \\
\text { Internet }\end{array}$ & 3 \\
\hline 22. & Trusted Insight & $\begin{array}{l}\text { Consumer } \\
\text { Internet }\end{array}$ & 3 \\
\hline 23. & Vault Dragon & $\begin{array}{l}\text { Consumer } \\
\text { Internet }\end{array}$ & 3 \\
\hline 24. & Vebbler & $\begin{array}{l}\text { Consumer } \\
\text { Internet }\end{array}$ & 3 \\
\hline 25. & VoiceMap & $\begin{array}{l}\text { Consumer } \\
\text { Internet }\end{array}$ & 3 \\
\hline 26. & WooMe & $\begin{array}{l}\text { Consumer } \\
\text { Internet }\end{array}$ & 3 \\
\hline 27. & Zippr & $\begin{array}{l}\text { Consumer } \\
\text { Internet }\end{array}$ & 3 \\
\hline 28. & Fab Alley & $\begin{array}{l}\text { E- } \\
\text { Commerce }\end{array}$ & 2 \\
\hline 29. & Stylhunt & $\begin{array}{l}\text { E- } \\
\text { Commerce }\end{array}$ & 2 \\
\hline 30. & Taembe & $\begin{array}{l}\text { E- } \\
\text { Commerce }\end{array}$ & 2 \\
\hline 31. & Eco Sense & Education & $\mathrm{n} / \mathrm{a}$ \\
\hline 32. & eHelium & Education & $\mathrm{n} / \mathrm{a}$ \\
\hline 33. & $\begin{array}{l}\text { India College } \\
\text { Search }\end{array}$ & Education & $\mathrm{n} / \mathrm{a}$ \\
\hline 34. & NetSpec Global & Education & $\mathrm{n} / \mathrm{a}$ \\
\hline 35. & Test Book & Education & $\mathrm{n} / \mathrm{a}$ \\
\hline 36. & CIMCON Lighting & Hardware & $\mathrm{n} / \mathrm{a}$ \\
\hline 37. & Fit Bark & Hardware & $\mathrm{n} / \mathrm{a}$ \\
\hline
\end{tabular}


INTERNATIONAL JOURNAL OF ACADEMIC RESEARCH IN BUSINESS AND SOCIAL SCIENCES Vol. 8, No. 7, July 2018, E-ISSN: 2222-6990 @ 2018 HRMARS

\begin{tabular}{|c|c|c|c|}
\hline 38. & $\begin{array}{l}\text { Wrig } \\
\text { Nanosystems }\end{array}$ & Hardware & $\mathrm{n} / \mathrm{a}$ \\
\hline 39. & Constant Therapy & $\begin{array}{l}\text { Health \& } \\
\text { Wellness }\end{array}$ & $\mathrm{n} / \mathrm{a}$ \\
\hline 40. & Healthist & $\begin{array}{l}\text { Health \& } \\
\text { Wellness }\end{array}$ & $\mathrm{n} / \mathrm{a}$ \\
\hline 41. & Map My Genome & $\begin{array}{l}\text { Health \& } \\
\text { Wellness }\end{array}$ & $\mathrm{n} / \mathrm{a}$ \\
\hline 42. & MyChild App & $\begin{array}{l}\text { Health \& } \\
\text { Wellness }\end{array}$ & $\mathrm{n} / \mathrm{a}$ \\
\hline 43. & Tagnos & $\begin{array}{l}\text { Health \& } \\
\text { Wellness }\end{array}$ & $\mathrm{n} / \mathrm{a}$ \\
\hline 44. & Tattva & $\begin{array}{l}\text { Health \& } \\
\text { Wellness }\end{array}$ & $\mathrm{n} / \mathrm{a}$ \\
\hline 45. & Vitas Pharma & $\begin{array}{l}\text { Health \& } \\
\text { Wellness }\end{array}$ & $\mathrm{n} / \mathrm{a}$ \\
\hline 46. & Wellness Forever & $\begin{array}{l}\text { Health \& } \\
\text { Wellness }\end{array}$ & $\mathrm{n} / \mathrm{a}$ \\
\hline 47. & $\begin{array}{l}\text { Wrig } \\
\text { Nanosystems }\end{array}$ & $\begin{array}{l}\text { Health \& } \\
\text { Wellness }\end{array}$ & $\mathrm{n} / \mathrm{a}$ \\
\hline 48. & Zakipoint Health & $\begin{array}{l}\text { Health \& } \\
\text { Wellness }\end{array}$ & $\mathrm{n} / \mathrm{a}$ \\
\hline 49. & Anchanto & Logistics & 2 \\
\hline 50. & Inthree & Logistics & 2 \\
\hline 51. & Logi Next & Logistics & 2 \\
\hline 52. & Quincus & Logistics & 2 \\
\hline 53. & Amigobulls & $\begin{array}{l}\text { Media \& } \\
\text { Content }\end{array}$ & 3 \\
\hline 54. & Baby Chakra & $\begin{array}{l}\text { Media \& } \\
\text { Content }\end{array}$ & 3 \\
\hline 55. & Dealstreet Asia & $\begin{array}{l}\text { Media \& } \\
\text { Content }\end{array}$ & 3 \\
\hline 56. & Inc42 & $\begin{array}{l}\text { Media \& } \\
\text { Content }\end{array}$ & 3 \\
\hline 57. & Little Black Book & $\begin{array}{l}\text { Media \& } \\
\text { Content }\end{array}$ & 3 \\
\hline 58. & $\begin{array}{l}\text { Mukunda Foods } \\
\text { Pvt. Ltd }\end{array}$ & Retail & $\mathrm{n} / \mathrm{a}$ \\
\hline 59. & Jay Robotix & Retail & $\mathrm{n} / \mathrm{a}$ \\
\hline 60. & Quik Tile & Retail & $\mathrm{n} / \mathrm{a}$ \\
\hline 61. & Wellness Forever & Retail & $\mathrm{n} / \mathrm{a}$ \\
\hline 62. & adStringO & SaaS & 3 \\
\hline 63. & Ascema & SaaS & 3 \\
\hline 64. & Digify & SaaS & 3 \\
\hline
\end{tabular}


INTERNATIONAL JOURNAL OF ACADEMIC RESEARCH IN BUSINESS AND SOCIAL SCIENCES Vol. 8, No. 7, July 2018, E-ISSN: 2222-6990 @ 2018 HRMARS

\begin{tabular}{|c|c|c|c|}
\hline 65. & Hatcher & SaaS & 3 \\
\hline 66. & JFDI Asia & SaaS & 3 \\
\hline 67. & LetsVenture & SaaS & 3 \\
\hline 68. & Mammoth & SaaS & 3 \\
\hline 69. & MassBlurb & SaaS & 3 \\
\hline 70. & NetSpec Global & SaaS & 3 \\
\hline 71. & POSist & SaaS & 3 \\
\hline 72. & Process Nine & SaaS & 3 \\
\hline 73. & SensiBol & SaaS & 3 \\
\hline 74. & $\begin{array}{l}\text { Silent Eight } \\
\text { Search }\end{array}$ & SaaS & 3 \\
\hline 75. & Tagnos & SaaS & 3 \\
\hline 76. & Viral Gains & SaaS & 3 \\
\hline 77. & RepUp & Tourism & 3 \\
\hline 78. & Routofy & Tourism & 3 \\
\hline 79. & Saraii Village & Tourism & 3 \\
\hline
\end{tabular}

* Code description: (1) Arts and Culture; (2) Design; and (3) Media.

The classification of creative industry sector funded by Angel Investor in Singapore as presented in table 3 above shows a relatively identical picture with the start-up condition of creative industry sector in Indonesia. The portion of start-up funding in almost $70 \%$ of total start-ups supported by SGAN is also found in the start-up condition of companies engaged in the creative industry sector in Indonesia.

However, to date throughout the author's knowledge, related studies on the contribution of angel investors to domestic economic growth in Indonesia, as well as economic growth in regional and / or global relative areas still do not exist. In addition, data on the achievements and performance of companies supported by angel investors in both countries are also relatively low so it cannot be known the real impact of funding angel investment on economic growth in the region.

\section{Conclusion}

The creative industry has an important role in economic growth in Indonesia. However, the lack of access to financing actors from the creative economy sector makes this sector difficult to grow so angel investors are needed to help the creative industry to grow. Since 2012, the angel in Indonesia began to be collected in a program called Angel Investment Network Indonesia (ANGIN). In the period 2012-2013 the contribution of creative industry to GDP Indonesia experienced a promising increase that also contributed to the increase in employment absorption. The angel in Singapore called Singapore Angel Network (SGAN). Almost 70\% of total start-ups supported by SGAN is also found in the start-up condition of companies engaged in the creative industry sector in Indonesia.

This shows that the creative industry sector in Indonesia should be supported especially in terms of financing as did Singapore. ANGIN should be able to increase the amount of startup funded because up to now there are 22 startups funded by ANGIN. The more startup funded by ANGIN, the greater the contribution the creative industry will bring to Indonesia's GDP so that the Indonesian economy will improve. 
INTERNATIONAL JOURNAL OF ACADEMIC RESEARCH IN BUSINESS AND SOCIAL SCIENCES

Vol. 8, No. 7, July 2018, E-ISSN: 2222-6990 (C) 2018 HRMARS

This paper encourages other researchers to make a relevant study on the relevance of angel investors' role towards the development of creative industry sector in Indonesia as well as in the regional sphere of ASEAN and internationally. So as to provide a real and up-to-date overview of the profile, role and contribution of investors to economic growth.

\section{References}

Anderson, J. (1996). Rewriting The History of Art Patronage. Journal of Society for Renaissance Studies, 10(2), 129-138.

Angel Investment Network Indonesia. http://angin.id/.

Arum, N. S. (2015). Angel Investment, Alternatif Pendanaan Bagi Pengusaha Pemula. Entrepreneur. January 18, 2018.

http://entrepreneur.bisnis.com/read/20150608/88/441150/angel-investment-alternatif-.

Badan Ekonomi Kreatif Indonesia. http://www.bekraf.go.id/.

Busenitz, L., Matusik, S., Anglin, A., \& Dushnitsky, G. (2017). A Review and Road Map of Entrepreneurial Equity Financing Research: Venture Capital, Corporate Venture Capital, Angel Investment, Crowdfunding, and Accelerators. Journal of Management, 20(10), 1-34.

Huang, L \& Pearce. J. L. (2015). Managing the Unknowable: The Effectiveness of Early-stage Investor Gut Feel in Entrepreneurial Investment Decisions. Administrative Science Quarterly, 60 (4), 634-670.

Li, Y., Jiang, S., Long, D., Tang, H., \& Wu, J. (2014). An exploratory study of business angels in China: a research note. Venture Capital: An International Journal of Entrepreneurial Finance, 16(1), 69-83.

Morrissette, S. G. (2007). A Profile of Angel Investors. Journal of Private Equity Summer, 10 (3), 5266.

Singapore Angel Network. https://www.sgan.sg/.

Wong, A., Bhatia, M., \& Freeman, Z. (2009). Angel finance: The other venture capital. Strategic Change, 18(7-8), 221-230. 